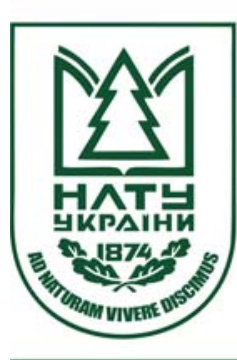

Науковий вісник НлтУ України

Scientific Bulletin of UNFU

https://nv.nltu.edu.ua

https://doi.org/10.36930/40310107

Article received 01.10.2020 p.

Article accepted 04.02.2021 p.

ISSN 1994-7836 (print)

ISSN 2519-2477 (online)

UDC 630*[416.16:244]

\begin{abstract}
${ }^{1}$ ДП "Новгород-Сіверська лісова науково-дослідна станція" УкрНДІЛГА ім. Г. М. Висоиького, м. Новгород-Сіверський, м. Новгород-Сіверський, Україна

${ }^{2}$ Національний природний парк "Деснянсько-Старогутський", м. Середино-Буда, Украйна
\end{abstract}

\title{
ДИНАМІКА ПОШИРЕННЯ ПРОЦЕСУ ВСИХАННЯ У СОСНОВИХ ДЕРЕВОСТАНАХ СХІДНОГО ПОЛІССЯ
}

\begin{abstract}
Проаналізовано динаміку осередків всихання за верхівковим типом з масовим поширенням верхівкового короїда Ips acuminatus у соснових насадженнях Східного Полісся впродовж періоду 2017-2019 рр. Охарактеризовано закономірності поширення процесу всихання у соснових деревостанах Східного Полісся на основі аналізу змін панівного типу всихання, що узгоджується з результатами лісопатологічного моніторингу просторово-часової мінливості осередків на пробних площах. Перші осередки групового відмирання дерев сосни звичайної виявлено упродовж 2015 р. у південно-західній частині Східного Полісся. Патологічне всихання поширювалося у східному напрямку, охопивши лісовий фонд усіх лісових господарств регіону. У західній частині зберігалась найбільша інтенсивність перебігу процесів всихання соснових деревостанів. В утворених осередках всихання відбувалася концентрація чисельності верхівкових короїдів 3 наступним заселенням суміжних дерев сосни, розширенням наявних та формуванням нових осередків. Встановлено переважання поодинокого та групового типу всихання у 2017 р., яке набуло куртинного типу з розширенням до суцільного у 2018 р. У 2019 р. на тлі зниження (до $34 \%$ ) інтенсивності виникнення нових осередків всихання виявлено розширення майже $25 \%$ минулорічних групових осередків, збільшення частки формування нових куртинних осередків всихання та появу осередків суцільного всихання. У 2019 р. інтенсивність процесів всихання істотно знизилася і стабілізувалися з переважанням поодинокого та групового типу. Появу нових та розширення минулорічних осередків у цьому році виявлено лише в другій половині вегетаційного періоду, що спричинило завершення розвитку лише однієї генерації верхівкового короїда. З'ясовано, що напрям поширення процесу всихання та виникнення нових осередків в соснових деревостанах стохастичний. В осередках всихання відмирали дерева різного діаметра з перевагою екземплярів більших ступенів товщини. Загальний відносний відпад за кількістю стовбурів в сосняках, які зазнали всихання, становив 31,3-46,3 \%, що зумовлювало погіршення їхнього санітарного стану 3 категорії дуже ослабленого до всихаючого із середнім індексом стану II,84-III,97.
\end{abstract}

Ключові слова: соснові деревостани; процеси всихання; осередок всихання; лісопатологічний маршрут; верхівковий короїд.

\section{Вступ}

Підтримання біологічної стійкості деревостанів $є$ одним 3 найважливіших критеріїв сталого розвитку лісового господарства. Порушення гомеостатичних зв'язків між компонентами лісового біогеоценозу призводять до зниження біологічної стійкості лісостанів [9, 20]. Соснові насадження Полісся України за останні роки потерпають від дії несприятливих погодно-кліматичних та антропогенних чинників, які зумовлюють ослаблення лісів та поширення шкідливих аборигенних та інвазійних комах і хвороб.

Соснові деревостани у Східному Поліссі України поширені на площі понад 290 тис. га, що становить 66,4 \% вкритих лісовою рослинністю земель [22]. Упродовж останніх років посилилася проблема всихання соснових насаджень та поширення в них верхівкового короїда Ips acuminatus (Gyllenhal, 1827) та інших стов- бурових шкідників. Сучасні кліматичні зміни призводять до погіршення умов росту, зниження біологічної стійкості, ослаблення дерев і, як наслідок, до активізації шкідливості комах і хвороб.

Для розроблення ефективних заходів з поліпшення стану та підвищення біологічної стійкості соснових лісостанів до негативного впливу екологічних чинників великого значення набуває вивчення особливостей перебігу процесів їхнього патологічного всихання.

Об'єкт дослідження - соснові деревостани з ознаками та осередками всихання у Східному Поліссі України.

Предмет дослідження - динаміка формування та розширення осередків всихання у сосняках Східного Полісся України.

Мета роботи - встановити особливості поширення патологічних процесів всихання у соснових деревостанах Східного Полісся України.

Для досягнення зазначеної мети визначено такі ос-

Інформація про авторів:

Жежкун Анатолій Миколайович, канд. с.-г. наук, директор. Email: desna-90@ukr.net

Порохняч Ігор Володимирович, канд. с.-г. наук, ст. наук. співробітник. Email: porohniaach.igor@gmail.com; https://orcid.org/0000-0002-7739-8921

Кубраков Сергій Володимирович, директор. Email: kubrak75@gmail.com

Цитування за Дсту: Жежкун А. М., Порохняч І. В., Кубраков С. В. Динаміка поширення процесу всихання у соснових деревостанах Східного Полісся. Науковий вісник НЛтУ України. 2021, т. 31, № 1. С. 42-47.

Citation APA: Zhezhkun, A. M., Porohnyach, I. V., \& Kubrakov, S. V. (2021). Dynamics of dieback spread in pine stands of Eastern Polissya. Scientific Bulletin of UNFU, 31(1), 42-47. https://doi.org/10.36930/40310107 
новні завдання дослідження:

- провести аналіз останніх досліджень та публікацій, що дасть змогу ефективно проаналізовати динаміку осередків всихання за верхівковим типом з масовим поширенням верхівкового короїда Ips acuminatus у соснових насадженнях Східного Полісся впродовж періоду 2017-2019 рр.;

- охарактеризувати матеріали та методи дослідження;

- навести результати дослідження та здійснити їх обговорення;

- зробити висновки та надати практичні рекомендації.

Наукова новизна отриманих результатів дослідження - вперше висвітлено регіональні особливості перебігу процесів патологічного всихання соснових деревостанів, які є панівними у Східному Поліссі України.

Практична значущість результатів дослідження можуть бути використані для розроблення ефективних заходів з підвищення стійкості деревостанів у регіоні досліджень.

Аналіз останніх досліджень та публікацій. Останні десятиріччя у різних регіонах світу спостерігається тенденція до збільшення обсягів розладнань лісових екосистем. Провідну роль в ослабленні деревостанів та формуванні осередків масового розмноження шкідливих комах $\epsilon$ несприятливі зміни погодно-кліматичних умов, серед яких основна роль належить рівню зволоження та температурному режиму $[5,14,16]$.

В Україні площа всихання соснових лісів охопила значну частину Полісся й поширилася на інші природні зони. Тому за останні роки у фаховій літературі нагромаджено значний обсяг публікацій щодо проблеми ослаблення, погіршення санітарного стану, всихання сос- нових лісостанів та поширення в них стовбурових ко$\max [1,3,4,6,7,8,11,19,21]$.

Матеріали та методи дослідження. Динаміку поширення осередків всихання соснових деревостанів у Східному Поліссі вивчали в умовах свіжого дубовососнового субору у лісових масивах трьох державних лісогосподарських підприємств (ДП "Добрянський лісгосп", ДП "Новгород-Сіверський лісгосп", ДП "Остерський військовий лісгосп"), а також господарської зони національного-природного парку Деснянсько-Старогутський. У лісових масивах окремих лісництв закладали лісопатологічний маршрут, який охоплював деревостани сосни звичайної різного віку з різним типом всихання. Упродовж 2017-2019 рр. уздовж маршрутної лінії на 50-70 м вглиб насаджень здійснювали рекогносцирувальні та, за потреби, детальні обстеження. Під час лісопатологічного обстеження сосняків 3 ознаками та осередками всихання, визначали площу локалізації осередків всихання його тип, орієнтовний час утворення та поширення. Тип всихання осередку встановлювали за його площею: поодинокий, груповий (до 10 дерев), куртинний (до 0,25 га), суцільний (понад 0,25 га).

Детальні лісопатологічні дослідження за динамікою поширення осередків всихання у соснових насадженнях проводили на постійних пробних площах (ППП), закладених у 2017 р. у різних частинах території Східного Полісся (табл. 1). Їх закладали навколо діючих групових осередків відмирання дерев. Видалення сухостійних дерев на ділянках не проводили, спостерігаючи за природним перебігом патологічних процесів.

Табл. 1. Лісівничо-таксаційні показники досліджуваних соснових деревостанів, які зазнали всихання на постійних моніторингових пробних площах

\begin{tabular}{|c|c|c|c|c|c|c|c|c|}
\hline \multirow[b]{2}{*}{$\begin{array}{c}\text { Підприємство, лісництво, } \\
\text { шифр ППП }\end{array}$} & \multirow[b]{2}{*}{$\begin{array}{l}\text { Квартал, } \\
\text { виділ }\end{array}$} & \multirow[b]{2}{*}{$\begin{array}{c}\text { Площа виділу } \\
\text { пробної } \\
\text { площі, га }\end{array}$} & \multirow[b]{2}{*}{$\begin{array}{l}\text { Тип лісу, склад } \\
\text { деревостану }\end{array}$} & \multicolumn{5}{|c|}{ Коротка таксаційна характеристика } \\
\hline & & & & $\begin{array}{l}\text { вік, } \\
\text { років }\end{array}$ & $\begin{array}{c}\text { середня } \\
\text { висота, } \\
\text { м }\end{array}$ & $\begin{array}{c}\text { середній } \\
\text { діаметр, } \\
\text { см }\end{array}$ & повнота & $\begin{array}{c}\text { Запас, } \\
\text { м }^{3} / \text { га }\end{array}$ \\
\hline $\begin{array}{c}\text { ДП "Добрянський лісгосп", } \\
\text { Комарівське, 1-Ком }\end{array}$ & 33,7 & $\frac{1,9}{0,28}$ & $\frac{\mathrm{B}_{2}}{10} \frac{-\mathrm{-L}}{\mathrm{C}}$ & 97 & 28 & 32 & 0,65 & 410 \\
\hline $\begin{array}{c}\text { ДП "Корюківський лісгосп", Брець- } \\
\text { ке, 1-Брц }\end{array}$ & 1,16 & $\frac{4,0}{0,50}$ & 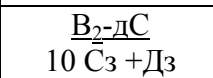 & 125 & 27 & 44 & 0,31 & 174 \\
\hline $\begin{array}{c}\text { ДП "Чернігівський лісгосп", } \\
\text { Мекшунівське, 1-Мкш }\end{array}$ & 114,5 & $0, \frac{16}{114}$ & $\frac{\mathrm{B}_{2}-\frac{\mathrm{AC}}{10 \mathrm{C}}}{10}$ & 99 & 24 & 28 & 0,6 & 310 \\
\hline $\begin{array}{c}\text { НПП "Деснянсько-Старогутський", } \\
\text { Старогутське відділення }\end{array}$ & 92,4 & $\frac{7,8}{0,241}$ & $\frac{\mathrm{B}_{2}-\mathrm{-gC}}{10 \mathrm{C}}$ & 97 & 28 & 36 & 0,45 & 278 \\
\hline
\end{tabular}

Закладання постійних пробних площ та розрахунки таксаційних показників деревостанів проводили згідно зі загальноприйнятими методиками [2, 10] відповідно до нормативно-довідкових матеріалів [17, 18]. Стан деревостанів визначали за середнім індексом санітарного стану дерев $\left(\mathrm{I}^{\mathrm{c}}\right)$ та за показниками відпаду. Для встановлення санітарного стану кожного дерева використовували Санітарні правила в лісах України [15].

\section{Результати дослідження та їх обговорення}

Перші осередки групового всихання в сосняках Східного Полісся виявлено у 2015 р. у південно-західній його частині - на території ДП "Вищедубечанський лісгосп" Київського ОУЛМГ та ДП "Остерський лісгосп" Чернігівського ОУЛМГ. Упродовж 2017-2019 pp. патологічні процеси всихання поширювалися в регіоні із заходу на схід та охопили лісовий фонд усіх лісгоспів Східного Полісся. Ступінь поширення процесу всихання за панівним типом відрізнявся залежно від територіального розміщення: низький (переважно поодинокі та групові осередки) - ДП "Новгород-Сіверський лісгосп" на північному сході, середній (групові і куртинні осередки) - ДП "Добрянський лісгосп" на північному заході та високий (куртинний з розширенням до суцільного типу всихання) - ДП "Остерський військовий лісгосп" на південному заході (табл. 2).

За час досліджень найбільша кількість осередків всихання виникла у 2017 р. - 58,5 \% від загальної їхньої кількості за три роки. Аналіз динаміки осередків всихання на лісопатологічних маршрутах у соснових насадженнях Східного Полісся за типом всихання вказує на переважання поодинокого та групового всихання у цьому році (рис. 1).

Всихання дерев відбувалося за верхівковим типом 3 масовим поширенням верхівкового короїда, який зумовлював стрімку втрату життєздатності заселених ним ослаблених дерев [13]. У сформованих осередках всихання відбувалася концентрація чисельності короїдів, спричинюючи подальше заселення прилеглих дерев сосни та розширення осередків. 
Табл. 2. Характеристика лісопатологічних маршрутів у соснових насадженнях з ознаками та осередками всихання

\begin{tabular}{|c|c|c|c|c|c|c|c|c|}
\hline \multirow{2}{*}{$\begin{array}{l}\text { Державне лісогосподарське } \\
\text { підприємство, лісництво }\end{array}$} & \multirow{2}{*}{$\begin{array}{c}\text { Довжина, } \\
\text { км }\end{array}$} & \multicolumn{3}{|c|}{ Обстежені соснові деревостани } & \multicolumn{4}{|c|}{$\begin{array}{c}\text { Частка виявлених осередків за типом } \\
\text { всихання, \% } \\
\end{array}$} \\
\hline & & вік & кількість & $\begin{array}{l}3 \text { них } 3 \text { осередка- } \\
\text { ми всихання (\%) }\end{array}$ & $\begin{array}{c}\text { Пооди- } \\
\text { нокі }\end{array}$ & Групові & Куртинні & Суцільні \\
\hline $\begin{array}{c}\text { ДП "Новгород-Сіверський лісгосп", } \\
\text { Узруївське та Володимирівське }\end{array}$ & 4,5 & $57-103$ & 53 & $14(26,4)$ & 20,5 & 71,8 & 7,7 & - \\
\hline $\begin{array}{c}\text { ДП "Добрянський лісгсоп", Кома- } \\
\text { рівське }\end{array}$ & 4,0 & $58-103$ & 31 & $18(58,1)$ & 11,1 & 66,7 & 22,2 & - \\
\hline $\begin{array}{c}\text { ДП "Остерський військовий лісгосп", } \\
\text { Бондарівське }\end{array}$ & 6,0 & $44-106$ & 38 & $18(47,4)$ & 25,9 & 7,4 & 59,3 & 7,4 \\
\hline
\end{tabular}

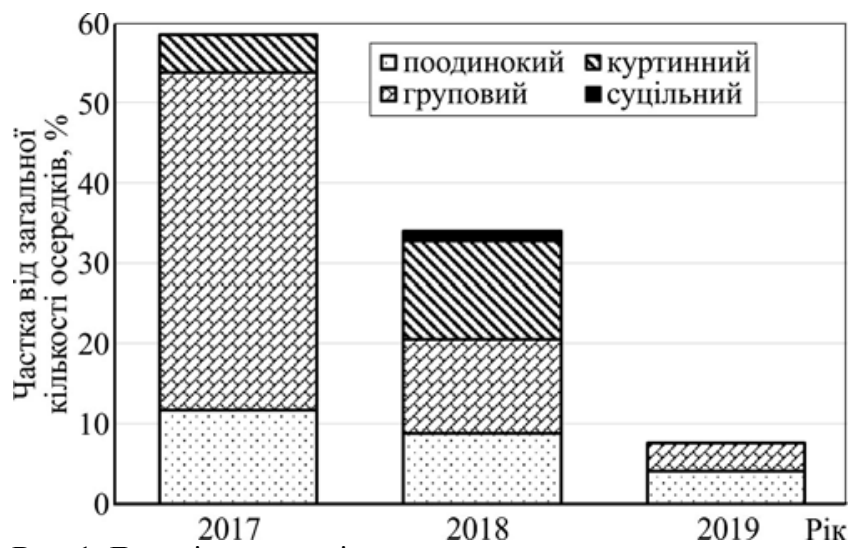

Рис. 1. Динаміка осередків всихання у соснових насадженнях Східного Полісся за типом всихання (2017-2019рр.)
У 2018 р. інтенсивність виникнення нових осередків знизилася - 33,9\% від кількості за період спостережень. Водночас відбувалося розширення майже $25 \%$ минулорічних групових осередків. Структура нових осередків в цьому році також змінилась порівняно з попереднім роком. Зросла кількісна частка формування нових куртинних осередків всихання, з'явилися осередки із суцільним типом всихання площею понад 0,25 га. У 2019 р. структура нових осередків набула істотних змін 3 переважанням поодинокого та групового типу всихання. Істотно знизилася інтенсивність процесів всихання порівняно з попередніми роками.

Аналіз динаміки панівного типу всихання у соснових насадженнях узгоджується з результатами моніторингу просторово-часової мінливості осередків на пробних площах (табл. 3).

Табл. 3. Розподіл дерев за категоріями санітарного стану та середня категорія санітарного стану дерев на постійних моніторингових пробних площах

\begin{tabular}{|c|c|c|c|c|c|c|c|c|c|c|c|}
\hline \multirow{2}{*}{ Дата обліку } & \multicolumn{6}{|c|}{ Частка дерев за категоріями санітарного стану, \% } & \multirow{2}{*}{$\begin{array}{l}\text { Індекс } \\
\text { стану }\end{array}$} & \multicolumn{2}{|c|}{ Життездатних дерев } & \multicolumn{2}{|c|}{ Відмерлі дерева } \\
\hline & I & II & III & IV & $\mathrm{V}$ & VI & & шт./га & $\%$ & шт./га & $\%$ \\
\hline \multicolumn{12}{|l|}{ 1-Брц } \\
\hline 27.04 .17 & - & 37,5 & 54,2 & 6,3 & - & 2,0 & II,73 & 47 & 97,9 & 1 & 2,1 \\
\hline 30.06 .17 & - & 37,5 & 43,7 & 6,3 & 10,5 & 2,0 & II,94 & 42 & 87,5 & 6 & 12,5 \\
\hline 09.11 .17 & - & 37,5 & 39,5 & 6,3 & 14,7 & 2,0 & III,02 & 40 & 83,3 & 8 & 16,7 \\
\hline 20.04 .18 & - & 37,5 & 39,6 & 4,2 & 2,1 & 16,7 & III,21 & 39 & 81,3 & 9 & 18,8 \\
\hline 20.07 .18 & - & 37,5 & 37,5 & - & 8,3 & 16,7 & III,29 & 36 & 75,0 & 12 & 25,0 \\
\hline 18.10 .18 & - & 37,5 & 31,3 & - & 14,6 & 16,7 & III,42 & 33 & 68,8 & 15 & 31,3 \\
\hline 03.05 .19 & - & 37,5 & 31,3 & - & - & 31,3 & III,56 & 33 & 68,8 & 15 & 31,3 \\
\hline 26.06 .19 & - & 37,5 & 31,3 & - & - & 31,3 & III,56 & 33 & 68,8 & 15 & 31,3 \\
\hline 21.08 .19 & - & 37,5 & 31,3 & - & - & 31,3 & III,56 & 33 & 68,8 & 15 & 31,3 \\
\hline 26.09 .19 & - & 33,3 & 27,1 & 0,0 & 8,3 & 31,3 & III,77 & 29 & 60,4 & 19 & 39,6 \\
\hline \multicolumn{12}{|l|}{ 1-Ком } \\
\hline 09.08 .2017 & 6,8 & 50,5 & 32,0 & 1,1 & 7,8 & 1,9 & II,58 & 93 & 90,4 & 10 & 9,7 \\
\hline 01.08 .2018 & 6,8 & 49,5 & 31,1 & 1,0 & 1,9 & 9,7 & II,71 & 91 & 88,4 & 12 & 11,6 \\
\hline 28.05 .2019 & - & 55,3 & 28,2 & 4,9 & - & 11,6 & II, 84 & 91 & 88,4 & 12 & 11,6 \\
\hline \multicolumn{12}{|l|}{ 1-Мкш } \\
\hline 27.09 .2017 & 4,9 & 41,5 & 14,6 & 17,1 & 17,1 & 4,9 & II,90 & 32 & 78,1 & 9 & 22 \\
\hline 31.10 .2017 & 2,4 & 39,0 & 19,5 & 7,3 & 26,8 & 4,9 & III,07 & 28 & 68,2 & 13 & 31,7 \\
\hline 05.09 .2018 & 2,4 & 34,1 & 14,6 & 2,4 & 14,6 & 31,7 & III,88 & 22 & 53,6 & 19 & 46,3 \\
\hline 26.06 .2019 & 2,4 & 31,7 & 17,1 & 2,4 & - & 46,3 & III,97 & 22 & 53,6 & 19 & 46,3 \\
\hline
\end{tabular}

На ППП 1-Брц у ДП "Корюківське ЛГ" упродовж 2017 р. відбувалося поступове розширення поодинокого осередку всихання та перетворення його у груповий iз 7 дерев сосни, які були заселені верхівковим короїдом. Показник градієнта відпаду становив 1,4, що $€$ свідченням початку патологічного відпаду дерев та формування осередку всихання. Внаслідок нагромадження поточного відпаду в кількості 14,6 \% загальної кількістю стовбурів санітарний стан деревостану за рік істотно погіршився зі зниженням індексу стану від II,73 до III,02. Насадження 3 категорії ослабленого на початку весни вже в середині літа перейшло до стану дуже ослабленого.
На початку вегетаційного періоду 2018 р. на пробній площі в осередку всихання виявлено одне дерево V категорії за санітарним станом, в середині- ще 3 таких дерева, а наприкінці року загальна кількість таких дерев становила 7 штук. Також у виділі за межами пробної площі у південно-східній частині ділянки виявлено ще один груповий осередок всихання з 4-х дерев свіжого сухостою, заселених верхівковим короїдом.

Отже, загальний поточний відпад у 2018 р. був аналогічним попередньому року і становив 14,6 \% від загальної кількості на ділянці. Це зумовило подальше зниження середнього індексу стану насадження до III,42. Значення градієнта відпаду близько 1,0 свідчить 
про продовження патологічного процесу всихання соснових природних старовікових деревостанів.

У 2019 р. інтенсивність всихання дерев сосни зменшилась більш ніж у 2 рази порівняно 3 показниками минулих років. Упродовж першої половини вегетаційного періоду появи дерев свіжого сухостою не відбувалося. Тільки наприкінці 2019 р. у південній частині ділянки виявлено 4 всохлі крупномірні дерева.

У центральній частині соснового деревостану на ППП 1-Ком у ДП "Добрянський лісгосп" у 2017 р. сформував груповий осередок 38 відмерлих дерев свіжого сухостою. Середній індекс санітарного стану $\left(\mathrm{I}^{\mathrm{C}}-\mathrm{II}, 58\right)$ характеризував деревостан як дуже ослаблений. Наступного року відбулось розширення осередку внаслідок всихання 2 дерев, що погіршило санітарний стан насадження $\left(\mathrm{I}^{\mathrm{C}}-\mathrm{II}, 71\right)$. Окрім цього відбулось поширення патологічного всихання на виділі за межами пробної площі у західному напрямку. Тут утворився груповий осередок всихання, який налічував 6 дерев свіжого сухостою, половина $з$ яких відмерла внаслідок заселення весняним поколінням верхівкового короїда, а інша частина - літнім. У 2019 р. припинилися процеси патологічного всихання на пробі та на виділі загалом. Деревостан залишався дуже ослабленим 3 переважанням дерев II та III категорій санітарного стану (I $\left.{ }^{\mathrm{C}}-\mathrm{II}, 84\right)$.

На ППП 1-Мкш у ДП "Чернігівський лісгосп" поширення процесу всихання розпочалося з формування осередку з групи 4 дерев сосни звичайної V категорії санітарного стану, заселених верхівковим короїдом навесні. Наприкінці вегетаційного періоду поточний відпад збільшився на 7 дерев свіжого сухостою внаслідок розвитку літньої генерації комах у південній частині пробної площі. Деревостан був дуже ослабленим $\left(\mathrm{I}^{\mathrm{C}}-\right.$ III,07). Наступного року осередок всихання збільшився на 6 дерев. Унаслідок нагромадження минулорічного сухостою відносний відпад за кількістю стовбурів досягав 46,3 \%, що позначилося на погіршенні санітарного стану деревостану ( $\left.\mathrm{I}^{\mathrm{C}}-\mathrm{III}, 88\right)$. Упродовж 2019 р. свіжого сухостою в деревостані не виявили.

Об'єкт дослідження розташований у межах заповідного урочища "Довга Рудня". Варто зазначити, що у заповідних урочищах поліських державних лісогосподарських підприємств Чернігівського ОУЛМГ площі соснових деревостанів з осередками всихання постійно збільшуються: у 2017 р. - 1,4 тис. га, 2018 р. 2,0 тис. га, у 2019 р. $-2,9$ тис. га.

У кв. 92, вид. 4 Старогутського відділення НПП "Деснянсько-Старогутський" всихання розпочалося у 2016 р. у північній частині виділу на ділянці завдовжки 217 м 3 формуванням 4 осередків на відстані 39-99 м (рис. 2). Всихання відбувалося за поодиноким (осередки № 1 і 3) та груповим типами (осередки № 5 і 6 , що містили 6 та 3 відмерлі дерева відповідно).

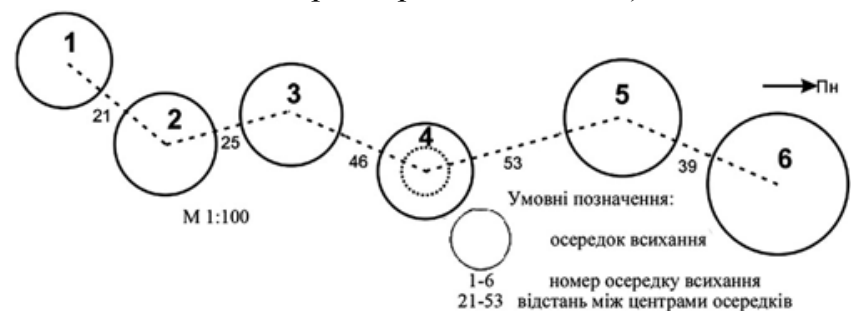

Рис. 2. Схема лісопатологічного маршруту з осередками всихання дерев сосни звичайної у кв. 92, вид. 4 Старогутського відділення НПП "Деснянсько-Старогутський" (на 26.09.2018 р.)
Упродовж наступного 2017 р. усі осередки всихання дерев минулого року розширилися, а всихання в насадженні цілком набуло групового типу. Поміж осередками № 1 та 3 утворився новий груповий осередок 32 відмерлих дерев (№ 2), та між осередками № 3 і 5 - поодинокий осередок (№ 4). Відстань між осередками всихання зменшилась до 9,5-29,0 м (табл. 4). У всіх осередках індекс стану коливався від II,78 до V,0. Переважна кількість дерев (67\%) відмерла внаслідок заселення та розвитку весняного покоління верхівкового короїда.

Табл. 4. Динаміка стану дерев сосни звичайної в осередках всихання

\begin{tabular}{|c|c|c|c|}
\hline \multirow{2}{*}{$\begin{array}{c}\text { oo осередку та } \\
\text { його розмір піс- }\end{array}$} & $\begin{array}{c}\text { Кількість відмерлих дерев сосни - у чисель- } \\
\text { лику та індекс стану - у знаменнику }\end{array}$ \\
\cline { 2 - 4 } & 2016 & 2017 & 2018 \\
\hline$\underline{1}$ & $\underline{1}$ & $\underline{3}$ & $\underline{3}$ \\
\hline 19,6 & 5,0 & 3,6 & 3,8 \\
\hline 2 & - & $\underline{2}$ & $\underline{2}$ \\
\hline 21,0 & $\underline{1}$ & 2,8 & 3,0 \\
\hline 3 & 5,0 & $\underline{6}$ & $\underline{6}$ \\
\hline 21,0 & - & 4,4 & 4,4 \\
\hline 4 & $\underline{6}$ & $\underline{1}, 0$ & $\underline{2}$ \\
\hline 9,8 & 4,2 & $\underline{10}$ & 3,1 \\
\hline 5 & $\underline{3}$ & 4,7 & $\underline{12}$ \\
\hline 24,0 & 2,9 & $\underline{4}$ & $\underline{8}$ \\
\hline 6 & $\underline{11}$ & $\underline{26}$ & 3,1 \\
\hline 29,0 & - & 3,6 & $\underline{33}$ \\
\hline Загалом & & & 3,9 \\
\hline & & & \\
\hline
\end{tabular}

Упродовж першої половини вегетаційного періоду нових та розширення минулорічних осередків всихання не виявили. Водночас наприкінці 2017 р. поширилися процеси всихання внаслідок розвитку тільки одного покоління верхівкового короїда. Розширилися минулорічний поодинокий осередок всихання (№ 4) і груповий осередок (№ 6), а осередок № 5 набув куртинного типу. Також виявлені відмерлі дерева за верхівковим типом всихання на відстані 15-25 м поза моніторинговими осередками. Напрям поширення процесу всихання в деревостані спрогнозувати не вдається.

Наприкінці вегетаційного періоду 2018 р. всихання деревостану охопило 61,8 \% довжини лісопатологічного

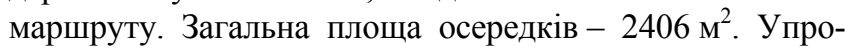
довж трьох років кількість всохлих дерев сосни звичайної збільшилось у 3 рази і становила 137 шт./га. Відповідно до розподілу дерев за ступенями товщини в осередках всихання відмирали дерева різного діаметра з перевагою екземплярів більших ступенів товщини (рис. 3).

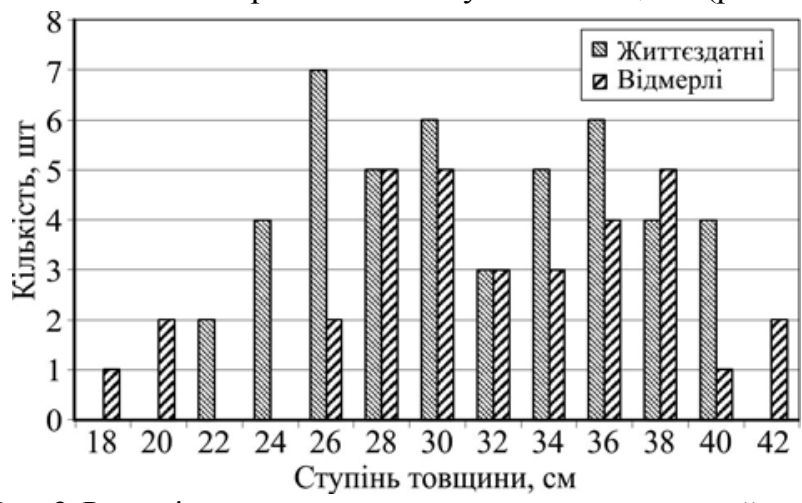

Рис. 3. Розподіл за ступенями товщини дерев сосни звичайної в осередках всихання після припинення всихання (на 26.09.2018 р.) 
У березні 2019 р. у деревостані проведено вибіркову санітарну рубку. Наприкінці 2019 р. у ліквідованих осередках всихання дерев сосни появи дерев свіжого сухостою не було. Внаслідок сприятливого гідротермічного режиму відбулося відновлення водозабезпечення дерев 3 інтенсифікацією смоловиділення, що підвищувало біологічну стійкість до заселення стовбуровими комахами [14].

\section{Висновки}

Формування осередків всихання в соснових насадженнях Східного Полісся розпочалося 3 поодинокого відмирання дерев упродовж 2015-2016 років. У 2017 р. переважало групове відмирання, що мало тенденцію до розширення 3 утворенням куртинних та суцільних осередків у 2018 р. У 2019 р. відбувалася істотне зниження інтенсивності поширення процесів всихання з переважанням поодинокого та групового типу. В осередках всихання відмирали дерева сосни різного діаметра 3 перевагою більших екземплярів. Загалом за три роки (2017-2019 рр.) у соснових деревостанах 3 ознаками всихання внаслідок поширення осередків патологічного відмирання дерев загальний відносний відпад за кількістю стовбурів становив 31,3-46,3 \%, а стан дуже ослаблених у такий спосіб деревостанів погіршувався до всихаючого (середній індекс- II,84-III,97). Всихання соснових деревостанів найбільш інтенсивно відбувається у західній частині Східного Полісся.

\section{References}

1. Andreieva, O. Yu., Guzii, A. I., \& Vyshnevskyi, A. V. (2018). Spread of bark beetles foci in pine stands of Rivne Polissya. Scientific Bulletin of UNFU, 28(3), 14-17. https://doi.org/10.15421/40280302

2. Anuchin, N. P. (1982). Forest taxation. Moscow: Forestry. [In Russian].

3. Borodavka, V., Getmanchuk, A., Kychylyuk, O., \& Voytyuk, V. (2016). Pathological processes of withering pine stands in Volyn Polissya. Scientific bulletin of the National University of Life and Environmental Sciences of Ukraine. Series: Forestry and decorative gardening, 238, 102-118. [In Ukrainian].

4. Burdulanyuk, A. O., Tatarynova, V. I., Vlasenko, V. A., et al. (2018). Dynamics of the number of bark beetles in the ecosystems of Polissya coniferousforests (Sumy oblast, Ukraine). Ukrainian Journal of Ecology, 8(2), 95-104. https://doi:10.15421/2018 315

5. Girs, G. I. (1982). Physiology weakening the tree. Novosibirsk: Nauka. [In Russian]

6. Hlasny, T., Krokene, P., Liebhold, A., et al. (2019). Living with bark beetles: impacts, outlook and management options. European Forest Institute, $236 \mathrm{p}$.

7. Jablonski, T., Tarwacki, G., \& Sukovata, L. (2019). Features of drying out in pine stands of Chernihiv region of Ukraine. Pine forests: current status, existing challenges and ways forward (Proce- edings of International Scientific and Practical Conference), 8388. Kyiv, Ukraine.

8. Krynytskyy, G. T., Kramarets, V. O., \& Matsiakh, I. P. (2019). Forestry and ecologicsl principles of pine forests protection. Pine forests: current status, existing challenges and ways forward (Proceedings of International Scientific and Practical Conference), 42 54. Kyiv, Ukraine.

9. Maurer, V. M. (2019). Etiology and pathogenesis of the mas drying pine stands. Pine forests: current status, existing challenges and ways forward (Proceedings of International Scientific and Practical Conference), 134-137. Kyiv, Ukraine.

10. Meshkova, V. L. (Ed.). (2010). Methodical recommendations for the survey of stem pest foci in the forest. Kharkiv: UkrNDILHA. 320 p. [In Ukrainian].

11. Meshkova, V. L., \& Borysenko, O. I. (2018). Prediction for bark beetles caused desiccation of pine stands. Forestry and Forest Melioration, 132, 155-161.

12. Mozolevskaya, E. G., Kataev, O. A., \& Sokolova, E. S. (1984). Methods of forest pathology examination centers of stem pests and diseases. Moscow: Forestry. 284 p. [In Russian].

13. Porohnyach, I. V. (2018). Features of spread Ips acuminatus Gyll. in Pine stands of Eastern Polissya. Forestry and Forest Melioration, 133, 136-141. https://doi.org/10.33220/10263365.133.2018.136

14. Porokhnyach, I. V. (2019). Role of meteorological factors in reducing the production of Ips acuminatus Gyll. in pine stands of Eastern Polissya. Forestry and Forest Melioration, 135, 184-192. https://doi.org/10.33220/1026-3365.135.2019.184

15. Sanitary rules in the forests of Ukraine. (1995). Approved by the resolution of the Cabinet of Ministers of Ukraine of 27.07.1995, No 555. Revision on 24.12.2019. Kyiv: Ukraine. [In Ukrainian].

16. Shvidenko, A. Z., \& Schepashchenko, D. G. (2013). Climatic changes and forest fires in Russia. Forestry, 5, 50-61. [In Russian].

17. Shvidenko, A. Z., Savich, Yu. N., Strochinsky, A. A., et al. (1987). Normative and reference materials for taxation of forests of Ukraine and Moldova. Kyiv: Harvest. [In Russian].

18. SOU 02.02. - 37-476:2006. (2006). Trial plots of forest management. Method of laying. Kyiv: Ministry of Agrarian Policy and Food of Ukraine. [In Ukrainian].

19. Turko, V. M., Vyshnevskyi, A. V., Siruk, Yu. V., \& Pecheniuk, Ye. P. (2016). Spreading diseases and pests in the Forests of Rivne region. Scientific Bulletin of UNFU, 26(5), 170-177. https://doi.org/10.15421/40260526

20. Zhezhkun, A. M. (2018). Conceptual basis and business events to maintain biological sustainability of forests. Main problems and tendencies of further development of forestry in the Ukrainian Carpathians (Proceedings of International Scientific and Practical Conference), 352-356. Ivano-Frankivsk. Ukraine.

21. Zhezhkun, A. M., Porohnyach, I. V. (2019). Features of drying out in pine stands of Chernihiv region of Ukraine. Pine forests: current status, existing challenges and ways forward (Proceedings of International Scientific and Practical Conference), 115-117. Kyiv, Ukraine.

22. Zhezhkun, A. N. (2014). Pine stands off Eastern Polissya: structure, state, productivity. Forestry and Forest Melioration, 124, 312. [In Ukrainian].

A. M. Zhezhkun', I. V. Porohnyach1, S. V. Kubrakov ${ }^{2}$

${ }^{I}$ SE "Novgorod-Siversk Forest Research Station" Ukrainian Research Institute of Forestry and Agroforestry named after Vysotsky, Novhorod-Siversk, Ukraine

${ }^{2}$ National Natural Park "Desnyansko-Starogutsky", Seredino-Buda, Ukraine

\section{DYNAMICS OF DIEBACK SPREAD IN PINE STANDS OF EASTERN POLISSYA}

In recent years, the problem of dieback of pine stands, which occupy $66.4 \%$ of the forest-covered lands of the region, has become more acute in Eastern Polissya of Ukraine. Pathological dieback of pine trees occurred in the apical type with a mass spread of Ips acuminatus (Gyllenhal, 1827). The dynamics of the spread of dieback foci in pine stands was studied on the established forest pathological routes, which covered pine stands of different ages with different types of drying, and trial plots around existing group dieback foci in accordance with generally accepted methods of forest-pathological and entomological research. The first group dieback foci of pine trees by apical type were discovered during the 2015 growing season. In the following years, pathological processes of dieback in pine stands spread in the region in the eastern direction, covering the forest fund of all forestry enterprises. The di- 
eback of pine stands took place most intensively in the western part of Eastern Polissya, where due to the expansion of the dieback foci, drying out of trees acquired certain and continuous type. The largest number of new dieback foci in pine stands appeared in 2017 (58.5\% of the total number for the period 2017-2019) with a predominance of group and single type. In the formed dieback foci there was a concentration of the number of Ips acuminatus with the subsequent colonization of adjacent pine trees, expansion of existing and formation of new foci of drying. The direction of the spread of drying and the emergence of dieback foci in the stands is stochastic. In 2018, the intensity of new dieback foci decreased to $34 \%$, but there was an expansion of almost $25 \%$ of last year's group foci of drying, an increase in the share of new curtains foci and foci with a continuous type of drying appeared. In 2018, the intensity of new drying foci decreased to $34 \%$, but there was an expansion of almost $25 \%$ of last year's group cells, an increase in the share of new curtains drying centers and there were cells with a continuous type of drying. In 2019 , the intensity of drying processes decreased significantly compared to previous years, so single and group cells prevailed. In general, for the period 2017-2019 in pine stands, that have dried up due to the spread of foci of pathological dieback of trees, the total relative of tree mortality by the number of trunks was 31.3-46.3\%, and the sanitary condition of the stands deteriorated from very weakened to withering.

Keywords: pine stands; drying processes; dieback foci; forest pathological route; Ips acuminatus. 